\title{
Bioprocess development for biolubricant production using microbial oil derived via fermentation from confectionery industry waste
}

Article

Accepted Version

Creative Commons: Attribution-Noncommercial-No Derivative Works 4.0

Papadaki, A., Vieira Fernandes, K., Chatzifragkou, A. ORCID: https://orcid.org/0000-0002-9255-7871, Gonçalves Aguieiras, E. C., Cavalcanti da Silva, J. A., Fernandez-Lafuente, R., Papanikolaou, S., Koutinas, A. and Guimarães Freire, D. M. (2018) Bioprocess development for biolubricant production using microbial oil derived via fermentation from confectionery industry waste. Bioresource Technology, 267. pp. 311-318. ISSN 0960-8524 doi:

https://doi.org/10.1016/j.biortech.2018.07.016 Available at https://centaur.reading.ac.uk/78104/

It is advisable to refer to the publisher's version if you intend to cite from the work. See Guidance on citing.

To link to this article DOI: http://dx.doi.org/10.1016/j.biortech.2018.07.016

Publisher: Elsevier 
copyright holders. Terms and conditions for use of this material are defined in the End User Agreement.

\section{www.reading.ac.uk/centaur}

\section{CentAUR}

Central Archive at the University of Reading

Reading's research outputs online 


\section{Accepted Manuscript}

Bioprocess development for biolubricant production using microbial oil derived via fermentation from confectionery industry waste

Aikaterini Papadaki, Keysson Vieira Fernandes, Afroditi Chatzifragkou, Erika Cristina Gonçalves Aguieiras, José André Cavalcanti da Silva, Roberto Fernandez-Lafuente, Seraphim Papanikolaou, Apostolis Koutinas, Denise Maria Guimarães Freire

PII: S0960-8524(18)30912-X

DOI: https://doi.org/10.1016/j.biortech.2018.07.016

Reference: BITE 20146

To appear in:

Bioresource Technology

Received Date: $\quad 26$ April 2018

Revised Date: $\quad 3$ July 2018

Accepted Date: $\quad 4$ July 2018

Please cite this article as: Papadaki, A., Fernandes, K.V., Chatzifragkou, A., Aguieiras, E.C.G., da Silva, J.A.C., Fernandez-Lafuente, R., Papanikolaou, S., Koutinas, A., Freire, D.M.G., Bioprocess development for biolubricant production using microbial oil derived via fermentation from confectionery industry waste, Bioresource Technology (2018), doi: https://doi.org/10.1016/j.biortech.2018.07.016

This is a PDF file of an unedited manuscript that has been accepted for publication. As a service to our customers we are providing this early version of the manuscript. The manuscript will undergo copyediting, typesetting, and review of the resulting proof before it is published in its final form. Please note that during the production process errors may be discovered which could affect the content, and all legal disclaimers that apply to the journal pertain. 


\section{Bioprocess development for biolubricant production using microbial oil derived via}

\section{fermentation from confectionery industry waste}

Aikaterini Papadaki ${ }^{1,+}$, Keysson Vieira Fernandes ${ }^{2,+}$, Afroditi Chatzifragkou ${ }^{1}$, Erika Cristina

Gonçalves Aguieiras ${ }^{2}$, José André Cavalcanti da Silva ${ }^{3}$, Roberto Fernandez-Lafuente ${ }^{4}$,

Seraphim Papanikolaou ${ }^{1}$, Apostolis Koutinas ${ }^{1, *}$, Denise Maria Guimarães Freire ${ }^{2}$

${ }^{1}$ Department of Food Science and Human Nutrition, Agricultural University of Athens, Iera Odos 75, 118 55, Athens, Greece.

${ }^{2}$ Department of Biochemistry, Institute of Chemistry, Federal University of Rio de Janeiro, Cidade Universitária, Centro de Tecnologia, BL A, SL 549, Ilha do Fundão, 21949-900, Rio de Janeiro, Brazil.

${ }^{3}$ Cenpes, Centro de Pesquisas Leopoldo Américo Miguez de Mello, Petrobras, Rio de Janeiro, Brazil.

${ }^{4}$ Departamento de Biocatálisis. ICP-CSIC. C/ Marie Curie 2. Campus UAM-CSIC. Cantoblanco. 28049 Madrid, Spain.

* Corresponding author: akoutinas@ @aua.gr (A. Koutinas)

${ }^{+}$Equally contributed as first authors 


\section{ABSTRACT}

Microbial oil produced from confectionery and wheat milling side streams has been evaluated as novel feedstock for biolubricant production. Nutrient-rich fermentation media were produced by a two-step bioprocess involving crude enzyme production by solid state fermentation followed by enzymatic hydrolysis of confectionery industry waste. Among 5 yeast strains and 2 fungal strains cultivated on the crude hydrolysate, Rhodosporidium toruloides and Cryptococcus curvatus were selected for further evaluation for biolubricant production based on fermentation efficiency and fatty acid composition. The extracted microbial oils were enzymatically hydrolysed and the free fatty acids were esterified by Lipomod 34-MDP in a solvent-free system with trimethylolpropane (TMP) and neopentyl glycol (NPG). The highest conversion yields were $88 \%$ and $82.7 \%$ for NPG esters of $R$. toruloides and C. curvatus, respectively. This study also demonstrates that NPG esters produced from microbial oil have promising physicochemical properties for bio-based lubricant formulations that could substitute for conventional lubricants.

Keywords: food industry side streams, microbial oil, bioprocess, biolubricants, enzymatic biocatalysis 


\section{Introduction}

Lubricants are oil-based chemicals, predominantly produced from mineral oil, which are widely used for minimizing the damage due to friction, wear, and overheating in machine parts (Garcés et al., 2011). The global lubricant demand was around 41.7 million $\mathrm{t}$ in 2015 (Anonymous, 2015). The major negative effect of petroleum based lubricants is associated with contamination of water and soil. Within the last decade, the production and use of conventional lubricants has been regulated by strict policies in order to minimize environmental pollution. In particular, the EU has established the "European Ecolabel for Lubricants" as an official EU mark for greener products and the Waste Framework Directive 2008/98/EC for the protection of the environment and human health from waste oils. Besides environmental pollution, the food industry demands the utilization of lubricants prepared from "generally recognized as safe" feedstocks. The USDA has categorized as H1 the lubricants used in applications where there is a possibility of incidental food contact and as $\mathrm{H} 2$ the lubricants used in applications where there is no possibility of food contact. Until now the formulation of food grade lubricants is based on the utilization of specific mineral oils and synthetic base oils, such as polyalphaolephins, polyalkalene glycols, and esters. The polyol and di-ester based lubricants have received $\mathrm{H} 2$ approval from USDA and mainly applied as oven chain and air compressor lubricants in the food and beverage industry (Rajewski et al., 2000).

The low toxicity, higher biodegrability, better lubricant properties and the lower emissions are the main advantageous characteristics of biolubricants over the lubricants produced from mineral oil. While the market for mineral-based finished lubricants has been stagnant, the market for biolubricants has shown an average growth of $10 \%$ per year over the last 10 years (Singh et al., 2015). In 2015, the global biolubricants market accounted for over $\$ 2$ billion (Anonymous, 2016). Biolubricants are produced from vegetable oils derived from 
palm, soybean, sunflower, rapeseed, coconut, jatropha and castor bean (Mobarak et al., 2014). However, the high demand for vegetable oils for biolubricant production requires increased agricultural area use leading to competition with food production (Ahmad et al., 2011). Thus, the utilization of microbial oil produced via fermentation of crude renewable resources could provide a sustainable feedstock for biolubricant production.

Microbial oil is a secondary metabolite produced mainly from algae, yeasts and fungi that could be used as renewable feedstock for the production of sustainable oleochemicals and fuels, such as wax esters and biodiesel (Leiva-Candia et al., 2015; Papadaki et al., 2017; Louhasakul et al., 2018). Bandhu et al. (2018) reported that the microbial oil of Rhodotorula mucilaginosa produced from sugar cane bagasse derived fermentation media had favorable fatty acid composition, physicochemical and tribophysical properties for good quality lubricant formulation.

The direct use of triglycerides and free fatty acids for biolubricant production present disadvantages, such as high viscosity, low volatility and lubrication capacity, polymerization during storage, and the generation of carbon residue after combustion (Pryde, 1983). Thus, the chemical modification of triglycerides or free fatty acids is mandatory for biolubricants production. Polyol based esters pose favourable lubricant properties and they exhibit a wide range of applications (da Silva et al., 2015; Greco-Duarte et al., 2017). The production of polyol esters is based on the esterification of carboxylic acids with polyols, such as trimethylolpropane and neopentyl glycol, using an acid or enzymatic catalyst. Conventional routes using homogeneous catalysts for the synthesis of biolubricants may lead to generation of impurities derived from the acidic catalyst, difficulties of catalyst recovery, necessity to treat the generated effluents and high water consumption during product purification (RoblesMedina et al., 2009). Thus, the use of enzymes as biocatalysts represents a sustainable process eliminating the problems associated with the application of conventional homogeneous 
catalysts. Enzymes present high specificity and selectivity preventing the formation of undesirable side products (Ferreira-Leitão et al., 2017). Lipases (glycerol ester hydrolases E.C. 3.1.1.3) catalyze the hydrolysis of tryacylglycerol releasing free fatty acids, di- and mono-acylglycerols, and glycerol. This class of enzymes can also catalyze esterification and transesterification in low-water content media (Aguieiras et al., 2015; Ferreira-Leitão et al., 2017). The successful utilization of enzyme biocatalysts for obtaining biolubricants has been extensively studied in previous studies using agricultural feedstocks or industrial side streams (da Silva et al., 2015; Greco-Duarte et al., 2017; Fernades et al., 2018; Cavalcanti et al., 2018).

This study presents a novel bioprocess for the production of bio-based lubricants using microbial oil derived from food processing side streams. A commercial lipase was used as biocatalyst for the hydrolysis of triglycerides to free fatty acids that were subsequently converted into polyol esters the composition of which was determined via NMR analysis. The physicochemical properties of the biolubricants, such as acid value, pour point, cloud point, viscosity and oxidative stability, were evaluated. The main aim of this study was the production of polyol esters with lubricant properties at low energy and chemical consumption via the solvent-free enzymatic catalysis that could substitute for conventional petroleumderived lubricants.

\section{Materials and methods}

\subsection{Microorganisms and enzymes}

The fungal strain Aspergillus awamori 2B.361 U2/1 was kindly provided by Professor Colin Webb (University of Manchester, UK). The purification, sporulation and storage conditions of A. awamori spores have been described previously (Koutinas et al., 2001; Tsakona et al., 2014). 
The yeast strains Rhodosporidium toruloides DSMZ 4444, Rhodosporidium toruloides

NRRL Y-27012, Rhodotorula glutinis NRRL YB-252, Cryptococcus curvatus ATCC 20509, Cryptococcus curvatus NRRL Y-1511 and the fungal strains Cunninghamella echinulata ATHUM 4411 and Mortierella ramanniana MUCL 2935 were utilized for microbial oil production. The microorganisms were maintained at $4{ }^{\circ} \mathrm{C}$ on agar slopes containing: yeast extract $(10 \mathrm{~g} / \mathrm{L})$, peptone $(10 \mathrm{~g} / \mathrm{L})$, dextrose $(10 \mathrm{~g} / \mathrm{L})$ and agar $(2 \%, \mathrm{w} / \mathrm{v})($ YPDA) for yeasts and potato dextrose agar (PDA, Lab M) for fungi.

The lipase Lipomod 34MDP derived from Candida rugosa was purchased from Biocatalyst.

\subsection{Fermentation media production and polyols}

Wheat milling by-products were utilized as substrate in solid state fermentation (SSF) of $A$. awamori. Flour rich waste streams (FRW) were supplied by the Greek confectionery industry Jotis S.A. and were used as raw material for the production of fermentation media using the enzyme-rich SSF solids. The FRW stream used in this study was derived from the production of food for infants and contained mainly starch $(84.8 \%)$, protein $(7.3 \%)$ and moisture (5\%). The production of crude enzyme consortia through the SSF of A. awamori and the hydrolysis of FRW streams were performed according to the methodology described by Tsakona et al. (2014). The resulted FRW hydrolysate was appropriately diluted and filter sterilized using a $0.2 \mu \mathrm{m}$ filter unit (Polycap TM AS, Whatman Ltd.).

The polyols trimethylolpropane (TMP) and the neopentyl glycol (NPG) used in the esterification reactions were purchased from Sigma-Aldrich.

2.3 Shake flask fermentations for microbial oil production 
Batch fermentations were conducted in $250 \mathrm{~mL}$ Erlenmeyer flasks using $50 \mathrm{~mL}$ of FRW hydrolysate. The hydrolysate was diluted in order to obtain a final glucose and free amino nitrogen (FAN) concentration of around $90 \mathrm{~g} / \mathrm{L}$ and $150 \mathrm{mg} / \mathrm{L}$, respectively. Inoculation was performed by adding $2 \%(\mathrm{v} / \mathrm{v})$ of $24 \mathrm{~h}$ preculture containing YPDA medium in the case of yeasts, or aqueous spore suspension containing $10^{6}$ spores $/ \mathrm{mL}$ produced by PDA cultures of fungi. Incubation was carried out at $28{ }^{\circ} \mathrm{C}$ in the case of $R$. toruloides strains and $R$. glutinis and at $30^{\circ} \mathrm{C}$ in the case of $C$. curvatus strains, C. echinulata and $M$. ramanniana using an orbital shaker (ZHWY-211C Series Floor Model Incubator, PR China) agitated at $180 \mathrm{rpm}$. The $\mathrm{pH}$ was regulated manually at the optimum level during each fermentation using $5 \mathrm{M} \mathrm{HCl}$ or $5 \mathrm{M} \mathrm{NaOH}$. Fermentations were carried out in duplicate and data represent the mean values.

\subsection{Microbial oil extraction and hydrolysis}

The microbial mass was collected by centrifugation $\left(9000 \times \mathrm{g}, 4^{\circ} \mathrm{C}, 10 \mathrm{~min}\right)$, washed twice with deionized water and lyophilized. The disruption of dried cells was performed as described by Tsakona et al. (2014). A chloroform:methanol solution at 2:1 (v/v) ratio was employed for the extraction of microbial oil. The solvent from the extracted microbial oil was removed by vacuum evaporation.

The extracted microbial oil was hydrolysed via solvent-free enzymatic catalysis using the lipase Lipomod 34MDP in $250 \mathrm{~mL}$ spherical flasks containing microbial oil and $0.1 \mathrm{M}$ Tris- $\mathrm{HCl}$ buffer at $\mathrm{pH} 8$ and a ratio of $1: 1(\mathrm{v} / \mathrm{v})$. After equilibration of the substrate at $30{ }^{\circ} \mathrm{C}$ in a temperature controlled water bath, 2\% (w/w, by oil) of Lipomod 34MDP was added to initiate the hydrolysis using magnetic agitation. The reaction was terminated after $24 \mathrm{~h}$ by adding hexane. The reaction mixture was transferred in a separation funnel in order to obtain the free fatty acid fraction. The lower layer that contained the buffer, glycerol and biocatalyst 
was discarded and the upper layer containing the solubilised free fatty acids in hexane was collected. The solvent was removed by vacuum evaporation. The acidity of the hydrolysed microbial oil (HMO) was measured by titration against $0.04 \mathrm{M} \mathrm{NaOH}$ using an autotitrator. The HMO was further evaluated for bio-based lubricant production.

\subsection{Biolubricant production}

The esterification reactions between the HMO and the polyols (TMP or NPG) were carried out in $50 \mathrm{~mL}$ round bottom flasks, which were temperature controlled in a water bath and agitated using a magnetic stirrer. The esterification conditions (i.e. substrate to molar ratio, enzyme concentration and temperature) were selected based on previous literature-cited publications (Greco-Duarte et al., 2017; Fernandes et al., 2018). In the case of HMO:TMP the molar ratio used was 3:1, whereas in the case of HMO:NPG the molar ratio used was 2:1. All reactions were carried out after the addition of $1 \%$ distilled water. The temperature was set at $45^{\circ} \mathrm{C}$ and the enzyme used was added at $4 \%$ (w/w, based on the reaction quantity). Samples of $100 \mu \mathrm{l}$ were taken at specific intervals (from $5 \mathrm{~min}$ to $72 \mathrm{~h}$ ). The reaction mixture was centrifuged $(8000 \times \mathrm{g}, 5 \mathrm{~min})$ in order to separate the enzyme from the product containing the polyol esters and some non-reacted polyols and fatty acids, which was collected for further analysis. The reactions were conducted in duplicate and data represent the mean values. The determination of the conversion yield $(\%)$ of fatty acids into polyol esters was based on the difference of acidity between the substrate and the product. Specifically, a precisely weighted sample was diluted in $40 \mathrm{~mL}$ of acetone:ethanol solution $(1: 1 \mathrm{v} / \mathrm{v})$ followed by titration with $0.04 \mathrm{M} \mathrm{NaOH}$ using an autotitrator. The acidity was calculated using the equation:

$$
\operatorname{Acidity}(\%)=\frac{V * M * F A}{w}
$$


where $V$ is the volume of $\mathrm{NaOH}$ used for titration, $M$ is the $\mathrm{NaOH}$ molarity, $F A$ is the molecular weight of the fatty acids, and $w$ is the weight of the sample used for titration.

The conversion of the free fatty acids into the non-acidic product was determined using the equation:

$$
\text { Conversion yield }(\%)=\frac{(A i-A f)}{A i} * 100
$$

where $A i$ is the initial acidity and $A f$ is the final acidity.

The calculation of conversion yields were given using the estimated modification of hydroxyl groups, calculated from the decrease in acidity.

\subsection{Analytical methods}

The fermentation was monitored by taking samples at regular intervals, following centrifugation ( $9000 \mathrm{x} \mathrm{g}, 4^{\circ} \mathrm{C}, 10 \mathrm{~min}$ ). For the determination of total dry weight (TDW) the precipitated biomass was washed twice with deionized water and then was oven dried at 70 ${ }^{\circ} \mathrm{C}$ until constant weight. The supernatant was used for the analysis of sugar consumption and other metabolic products using High Performance Liquid Chromatography (HPLC) analysis (Shimadzu) equipped with a Rezex ROA-organic acid H+ column (300 mm length x $7.8 \mathrm{~mm}$ internal diameter, Phenomenex) coupled to a differential refractometer. The mobile phase was a solution of $10 \mathrm{mM} \mathrm{H}_{2} \mathrm{SO}_{4}$ with $0.6 \mathrm{~mL} / \mathrm{min}$ flow rate and $65^{\circ} \mathrm{C}$ column temperature. The sugar consumption and the oil production was expressed as g per L of fermentation and the intracellular yield as the percentage of $\mathrm{g}$ of lipid produced per $100 \mathrm{~g}$ of TDW.

The FAN concentration of the hydrolysate was determined according to the analytical protocol described by Kachrimanidou et al. (2013).

The fatty acid profile of the different microbial oils were determined in a Fisons GC8060 gas chromatography equipped with a CPWAX 52CB column $(30 \mathrm{~m} \times 0.32 \mathrm{~mm}$ i.d., 0.25 
$\mu \mathrm{m}$ film thickness, Chrompack), a split/slpitless injector and a flame ionization detector (FID) as described by Papadaki et al. (2017).

The activity of the Lipomod 34MDP was measured using $25 \mathrm{mM}$ p-nitrophenyl laureate in acetonitrile/DMSO $(1: 1 \mathrm{v} / \mathrm{v})$ as substrate dissolved in $25 \mathrm{mM}$ phosphate buffer at pH 7.0 (Gutarra et al., 2009). One unit (U) of hydrolytic activity was defined as the amount of enzyme that releases $1 \mathrm{mmol}$ of p-nitrophenol per minute under the assay conditions. The hydrolytic activity for the Lipomod 34MDP used in this study was $10679 \mathrm{U} / \mathrm{g}$.

The analysis of the structure and purity of the synthesized products was carried out by ${ }^{1} \mathrm{H}$ and ${ }^{13} \mathrm{C}$ Nuclear Magnetic Resonance (NMR) using an Agilent INOVA-300 (7.05T) spectrometer. Samples were prepared in $\mathrm{CDCl}_{3}$ at $25{ }^{\circ} \mathrm{C}$, at $5 \%(1 \mathrm{H})$ and $20 \%{ }^{13} \mathrm{C}$ concentration and compared with the spectra of the pure chemical compounds.

The viscosity was measured using a calibrated viscometer tube (Cannon-Fenske) under two different temperatures, $40^{\circ} \mathrm{C}$, and $100^{\circ} \mathrm{C}$. The viscosity index (Vi) was calculated according to the ASTM D 2270 international viscosity index table.

The pour point was determined by the following procedure: after heating the sample was cooled at a specific speed and the characteristics of the flow were observed every $3^{\circ} \mathrm{C}$. The lowest temperature in which movement was observed was determined as the pour point.

The oxidative stability of HMP-TMP esters and HMO-NPG esters was studied using a Metrohm 679 Rancimat apparatus (Herisau, Switzerland). The analysis was carried out using $3 \mathrm{~g}$ of each sample at $110^{\circ} \mathrm{C}$ and an air flow rate of $10 \mathrm{~L} / \mathrm{h}$. Measurements were carried out in triplicate and the oxidative stability was expressed as induction time (h).

Differential scanning calorimetry (DSC) measurements were carried out in a DSC Q2000 (TA-Instruments) calorimeter calibrated for temperature and enthalpy by melting highpurity indium. The evaluated temperature range was $-60^{\circ} \mathrm{C}$ to $110^{\circ} \mathrm{C}$. 


\section{Results and discussion}

\subsection{Shake flasks fermentations}

The ability of different oleaginous yeasts and fungi to accumulate intracellularly microbial oil was evaluated through batch fermentations in shake flasks using the FRW hydrolysate as substrate. The results presented in Table 1 demonstrate that the FRW hydrolysate was efficiently utilized by all yeast and fungal strains. Among the oleaginous yeasts used, the highest lipid concentrations were observed in the case of $R$. toruloides DSM 4444 (9.5 g/L) and C. curvatus ATCC 20509 (5.8 g/L) with intracellular lipid contents of $41.1 \%(\mathrm{w} / \mathrm{w})$ and $16.5 \%(\mathrm{w} / \mathrm{w})$. The final microbial lipid concentrations produced by the oleaginous fungal strains M. ramanniana and C. echinulata were $11.7 \mathrm{~g} / \mathrm{L}$ and $9.2 \mathrm{~g} / \mathrm{L}$, respectively, with lipid contents of $39.8 \%(\mathrm{w} / \mathrm{w})$ and $35.3 \%(\mathrm{w} / \mathrm{w})$, respectively.

Efficient lipid production by the oleaginous yeasts $R$. toruloides DSM 4444 and $C$. curvatus ATCC 20509 has been previously demonstrated using confectionery industry waste, cheese whey and wine lees (Kopsahelis et al., 2018; Tsakona et al., 2016). The oleaginous yeast $R$. toruloides DSM 4444 reached $37.8 \mathrm{~g} / \mathrm{L}$ of microbial lipids in fed-batch fermentations carried out using FWR hydrolysate as substrate with an intracellular lipid content of $61.8 \%$ (w/w) (Tsakona et al., 2016). The oleaginous yeast C. curvatus ATCC 20509 have shown high lipid production $(33.1 \mathrm{~g} / \mathrm{L})$ when cultivated on a co-substrate consisting of lactose from cheese whey and a nutrient rich hydrolysate derived from wine lees (Kopsahelis et al., 2018).

\subsection{Fatty acids composition of microbial oils}

Since the yeasts $C$. curvatus ATCC 20509, $R$. toruloides DSM 4444 and $R$. toruloides NRRL Y-27012 and the two fungal strains produced the highest lipid concentrations, they were selected for further analysis of their fatty acid composition (Table 2). The fatty acid composition was used as a screening criterion in order to select suitable microbial oils for 
biolubricant production. The microbial oils produced by yeast strains contained mainly oleic acid $(52.7-55.3 \%)$, palmitic acid $(24.2-28.2 \%)$, stearic acid $(6.5-10.8 \%)$, linoleic acid $(7.4-9.5 \%)$ and low quantities of $\alpha$-linolenic acid $(0.7-2.1 \%)$. The microbial oils produced by fungal strains contained mainly oleic acid (ca. 49\%), palmitic acid (15.1 - 20.8\%), linoleic acid $(16.2-17.5 \%), \gamma$-linolenic acid $(7.1-11.8 \%)$ and low quantities of stearic acid $(2.9-$ $3.7 \%$ ). The content of saturated fatty acids in the microbial oils was higher in the case of oleaginous yeasts $(32.3-37.6 \%)$ than oleaginous fungal strains $(18.4-25.5 \%)$. Oils with lower content of saturated fatty acids lead to improved pour point and viscosity of the biolubricants produced as esterified fatty acids (Allen et al., 1999; Sarin et al., 2009). On the other hand, the microbial oils derived from fungal strains contained high amounts of polyunsaturated fatty acids $(23.3-29.3 \%)$, which could affect negatively the properties of the biolubricants by promoting autoxidation (Fox and Stachowiak, 2007). Sharma et al. (2015) reported that biolubricants produced from high-oleic acid vegetable oils, such as soybean oil, could substitute mineral oil-based lubricants. However, vegetable-based lubricants are generally characterized by poor oxidative stability, which can be improved by the removal or the reduction of polyunsatured fatty acids present in the oil. The microbial oils derived from the yeasts $C$. curvatus ATCC 20509 and $R$. toruloides DSM 4444 presented the lowest content of unsaturated fatty acids and for this reason they were selected for ester production.

\subsection{Biolubricants production}

The production of biolubricants was monitored during enzymatic reaction by recording the reduction of the acidity caused by the esterification of free fatty acids because analytical standards for the esters formed are not commercially available. Therefore, the microbial oil was enzymatically hydrolysed into free fatty acids. The initial acidity of the microbial oil was $11 \%$ and after $24 \mathrm{~h}$ of enzymatic hydrolysis the acidity was increased to 
96\%. Figure 1 presents the conversion yield of HMO of C. curvatus to TMP and NPG esters. The conversion yield of both esters reached $78.5 \%$ and $68.5 \%$ in the case of NPG and TMP, respectively, after $24 \mathrm{~h}$. At $72 \mathrm{~h}$, the conversion yield of NPG and TMP esters were $82.7 \%$ and $75.9 \%$, respectively. Figure 2 presents the conversion yield of HMO of $R$. toruloides to TMP and NPG esters. Furthermore, the highest conversion yield was also achieved in the case of NPG-esters $(85.7 \%)$ than TMP esters $(82.9 \%)$ after $24 \mathrm{~h}$. The conversion yield was increased to $88 \%$ for NPG esters and $83 \%$ for TMP esters at $72 \mathrm{~h}$. The NPG esters were produced at a higher rate than TMP esters in the first 15 min of the enzymatic reaction when the HMO of $R$. toruloides was used. This could be explained by the higher solubility of NPG in the HMO than TMP. However, the esterification of HMO of $R$. toruloides with TMP reached a similar conversion yield with NPG esters after $24 \mathrm{~h}$. The addition of surplus quantity of free fatty acids could increase the modification of the polyols for each reaction, but it would also lead to an acid product that must be treated further in order to produce a commercially acceptable biolubricant, which could lead to an increased cost of the final product (Alkio et al., 2000).

The present study reports for the first time the enzymatic production of polyol esters as biolubricants using microbial oil produced by oleaginous yeasts. Although there are no many studies concerning the utilization of NPG polyol, the esterification of fatty acids derived from vegetable oils with TMP has been described in literature-cited publications. Uosukainen et al. (1998) reported a conversion yield of $75 \%$ using TMP and rapeseed oil after $24 \mathrm{~h}$ reaction that was carried out at similar molar ratio $(3: 1)$ and temperature $\left(37^{\circ} \mathrm{C}\right)$ to those described in this work, but higher concentration of a lipase produced by Candida rugosa (40\%). A high conversion yield (90\%) was achieved after $68 \mathrm{~h}$ when the temperature was increased to $47^{\circ} \mathrm{C}$ (Uosukainen et al., 1998). The esterification of oleic acid with TMP by $2 \%$ of Candida antarctica lipase at $60^{\circ} \mathrm{C}$ led to a conversion yield of $80 \%$ after $50 \mathrm{~h}$ (Åkerman et al., 2011). 
Enzymatic esterification is more advantageous than chemical conversion due to the milder operating conditions employed. For instance, the synthesis of TMP triesters using palm oil and calcium methoxide as catalyst (Chang et al., 2012) or oleic acid and methylbenzene as catalyst (Quiao et al., 2017) require high temperatures $\left(180^{\circ} \mathrm{C}\right)$ in order to achieve high conversion yields.

3.4 Nuclear magnetic resonance analysis

The composition of TMP and NPG esters concerning the content of tri-, di- and monoesters was determined via NMR analysis (Tables 3 and 4). The esterification (24 h) carried out using the HMO of $C$. curvatus with TMP produced mainly triesters $(68.1 \%, \mathrm{w} / \mathrm{w})$ and diesters $(22.1 \%, \mathrm{w} / \mathrm{w})$, while the non-esterified TMP was only $0.5 \%(\mathrm{w} / \mathrm{w})$ corresponding to $13.25 \%$ of free hydroxyl groups (Table 3). A monesters fraction was not detected when TMP was esterified with HMO of $C$. curvatus. The product formed after $24 \mathrm{~h}$ between HMO of $R$. toruloides and TMP consisted of triesters $(58.2 \%, \mathrm{w} / \mathrm{w})$, diesters $(20.7 \%, \mathrm{w} / \mathrm{w})$ and monoesters $(10.8 \%, \mathrm{w} / \mathrm{w})$, while the non-esterified TMP was $2 \%(\mathrm{w} / \mathrm{w})$ corresponding to $25.77 \%$ of free hydroxyl groups (Table 3).

The NMR analysis concerning the production of NPG esters showed that the esters produced from HMO of $R$. toruloides contained a higher monoester content $(35.3 \%, \mathrm{w} / \mathrm{w})$ and a lower diester content $(53.6 \%, \mathrm{w} / \mathrm{w})$ than the monoester $(13.6 \%, \mathrm{w} / \mathrm{w})$ and diester $(78 \%$, $\mathrm{w} / \mathrm{w}$ ) content of the esters produced from HMO of $C$. curvatus (Table 4). The content of nonesterified hydroxyl groups was also lower in the case of NPG esters produced from HMO of C. curvatus (11.92\%) than the HMO of $R$. toruloides (32.4\%). This could be improved by using surplus free fatty acid content during esterification. Cavalcanti et al. (2018) reported that the enzymatic esterification of free fatty acids of soybean oil with TMP and NPG led to better results when the molar ratio of free fatty acids to polyol was 3.75:1 when either polyol 
was used. It was reported that under this condition the esterification reactions using NPG resulted to $100 \%$ esterification of the $\mathrm{OH}$ groups.

\subsection{Physicochemical characterization of biolubricants}

The highest conversion yields were obtained using NPG when HMO from either $C$. curvatus or $R$. toruloides was used. For this reason, the NPG esters were selected for the evaluation of their lubricant properties via physical and chemical characterization.

DSC analysis was employed in order to determine the melting points of the products. The thermogram of NPG - R. toruloides esters showed the main peak at $-10.47^{\circ} \mathrm{C}$ (Figure $3 \mathrm{a}$ ), but other smaller peaks appear around $-23^{\circ} \mathrm{C}$ and $-2{ }^{\circ} \mathrm{C}$. These peaks may represent a mixture of esters including mono- and di-esters (Zheng et al., 2011). Considering the lower melting point of unsaturated esters (Knothe and Dunn, 2009), it could be indicated that most of the peaks towards to the left of Figure 3a correspond to these esters. Other peaks representing melting temperatures over $0{ }^{\circ} \mathrm{C}$ also appeared and these may be attributed mostly to saturated esters. The thermogram of NPG - C. curvatus esters also presented several peaks with melting temperature lower than zero with the main peak appearing at $-8^{\circ} \mathrm{C}$ (Figure $3 b$ ). The melting temperatures observed for this product are slightly higher than those observed in the case of NPG - R. toruloides esters. Both microbial oils mainly contain palmitic acid and oleic acid. Thus, the melting temperatures of the polyol esters are similar to those reported for esters derived from these fatty acids (Knothe and Dunn, 2009).

The viscosity, pour point and oxidative stability were also determined (Table 5). The viscosity or viscosity index plays important role in lubrication, optimizing the working efficiency of the machinery and also preventing rubbing and collision between the components (Ting and Chen, 2011). Biolubricants do not have a specific pre-defined minimum value of viscosity, and specific applications can be chosen based on the lubricants 
classification according to their ISO grades (Bock, 2007). Lubricants in current commercial use reach a range of ISO from $<10$ to $>1000$ based on viscosity values $\left(\mathrm{mm} / \mathrm{s}^{2}\right)$ at $40{ }^{\circ} \mathrm{C}$. Both NPG esters of $R$. toruloides $\left(22.33 \mathrm{~mm} / \mathrm{s}^{2}\right)$ and $C$. curvatus $\left(23.84 \mathrm{~mm} / \mathrm{s}^{2}\right)$ showed similar viscosity values at $40^{\circ} \mathrm{C}$, which classifies them to the ISO VG $22\left(19.8-24.2 \mathrm{~mm} / \mathrm{s}^{2}\right)$. This ISO grade allows the utilization of these esters as chainsaw lubricant, total loss lubricant, mold release fluid for concrete and hydraulic fluid (VanVoorst and Alam, 2000). Cavalcanti et al. (2018) reported that the NPG esters derived from soybean oil was also classified to VG 22. The NPG esters of $R$. toruloides and C. curvatus oils had similar viscosity index (181183). The viscosity index of the NPG esters produced via enzymatic esterification of NPG with free fatty acids derived from soybean oil was 214 (Cavalcanti et al., 2018).

The cold flow temperature properties of the NPG-based esters were determined by the cloud point and pour point analysis. The pour point indicates the lowest temperature at which the lubricant flows and in practice this is the lowest temperature at which the biolubricant is pumpable (Mobarak et al., 2014). The cloud point is the temperature at which dissolved solids, like wax crystals, start to solidify giving a cloudy appearance. The determination of cloud point is essential for cold temperature applications, since the presence of solidified waxes cause thickening of the biolubricants. Furthermore, the operation temperature should be kept above the cloud point in order to prevent clogging of filters (Mobarak et al., 2014).

The pour point of the NPG esters $\left(2-3{ }^{\circ} \mathrm{C}\right)$ derived from both HMO used in this study (Table 5) is considered high for lubrication at low operating temperatures. However, at this pour point, the biolubricants could be used for lubrication of chainsaw and also as dustsuppressant fluids in countries or seasons where the temperature does not drop below $5{ }^{\circ} \mathrm{C}$. Another possibility is the utilization of biodegradable additives, which can decrease the pour point to more desirable temperatures (Asadauskas and Erhan, 1999; Macpherson, 1997). Pour point depressants can improve the biolubricant performance at low temperatures even when 
they are used in very low concentrations. Soybean oil-based lubricants produced using different alcohols presented variable pour points according to their structure, but all of them had their pour point temperatures decreased after the addition of $1 \%$ pour point depressants (v/v), achieving reduction up to $39^{\circ} \mathrm{C}\left(-6^{\circ} \mathrm{C}\right.$ before and $-45^{\circ} \mathrm{C}$ after pour point depressant addition) (Hwang and Erhan, 2001).

The cloud point of NPG esters produced from HMO of $R$. toruloides was $4{ }^{\circ} \mathrm{C}$, while the cloud point of NPG esters from HMO of C. curvatus was $6{ }^{\circ} \mathrm{C}$ (Table 5). The utilization of depressants can also decrease the cloud point of the products and extend their range of applications (Ming et al., 2005). The biolubricants produced from canola oil presented lower cloud point $\left(-3^{\circ} \mathrm{C}\right)$ and pour point $\left(-9^{\circ} \mathrm{C}\right)$ than the biolubricants produced in this study (Sharma et al., 2015). Generally, the poor cold flow properties of the biolubricants produced in this study should be improved in order to facilitate their applications in cold weather conditions. Besides addition of depressants, the NPG-HMO based esters could also be used in different blends with other esters in order to optimize their lubrication properties and applications.

The determination of oxidation stability is critical for the combustion process of engines (Sharma et al., 2015). Oxidation leads to an increase in the viscosity of lubricant and deposits varnish and sludge decreasing the lubricant lifetime. Thus, the oxidative stability of the product is one of the properties that decides the quality of the product and potential applications. The evaluation of oxidative stability showed that the induction times for NPG esters derived from HMO of $R$. toruloides was $3.29 \mathrm{~h}$, while the oxidative stability of the NPG esters derived from the HMO of $C$. curvatus was 4.18 h. Sripada et al. (2013) reported oxidative induction times at $110^{\circ} \mathrm{C}$ for TMP esters produced with either methyl oleate $(2.08$ h) or canola biodiesel (0.74 h) using sodium methoxide as catalyst (Sripada et al., 2013). TMP esters derived from cooking oil had an induction time of $3.5 \mathrm{~h}$ at $120^{\circ} \mathrm{C}$, which was decreased 
to $1.7 \mathrm{~h}$ when the temperature was increased to $130{ }^{\circ} \mathrm{C}$ (Wang et al., 2014). The oxidative stability is related to the fatty acid composition of the oil used (Singh et al., 2014). For instance, the oxidative induction time of NPG esters derived from palm fatty acid distillate was found higher than $69 \mathrm{~h}$ (Fernandes et al., 2018), due to the higher content of saturated fatty acids (48.7\%) than the microbial oils used in this study (37.6\%). The oxidative stability of the products can be improved by using additives, such as the commercially available antioxidant MP90, which significantly improved the induction time of TMP esters from cooking oil to $15.8 \mathrm{~h}$ at $130{ }^{\circ} \mathrm{C}$ (Wang et al., 2014).

\section{Conclusion}

A novel process has been presented for enzymatic production of polyol esters with lubricant properties using microbial oils produced via fermentation of food industry wastes. The oil produced by oleaginous yeasts presented higher content of saturated fatty acids than fungal strains, which is desirable for biolubricant production. High conversion yield was achieved during enzymatic ester production of NPG and TMP with HMO of $R$. toruloides and $C$. curvatus. The physicochemical properties of NPG-HMO derived esters showed that they could be used as biolubricants and specific properties could be improved after the use of additives.

\section{Acknowledgements}

The authors thank Petrobras (Brazil), the National Council for Scientific and Technological Development of the Ministry of Science, Technology and Innovation (CNPq/MCTI) through the Special Visiting Researcher fellowship (process number: 313772/2013-4) and MINECO from Spanish Government (CTQ2017-86170-R). The authors also thank Dr. Athanasios Mallouchos and Dr. Chrysavgi Gardeli from the Department of Food Science and Human 
Nutrition of the Agricultural University of Athens (Greece) for their assistance in the oxidation stability analysis. 


\section{References}

1. Aguieiras, E.C.G., Cavalcanti-Oliveira, E.D., Freire, D.M.G., 2015. Current status and new developments of biodiesel production using fungal lipases. Fuel 159, 52-67.

2. Ahmad, A.L., Yasin, N.H.M., Derek, C.J.C., Lim, J.K., 2011. Microalgae as a sustainable energy source for biodiesel production: A review. Renew. Sust. Energ. Rev. 15, 584-593.

3. Åkerman, C.O., Hagström, A.E.V., Mollaahmad, M.A., Karlsson, S., Hatti-Kaul, R., 2011. Biolubricant synthesis using immobilised lipase: Process optimisation of trimethylolpropane oleate production. Process Biochem. 46, 2225-2231.

4. Alkio, M., Gonzalez, C., Jäntti, M., Aaltonen, O., 2000. Purification of polyunsaturated fatty acid esters from tuna oil with supercritical fluid chromatography. J Amer. Oil Chem. Soc. $77,315-321$.

5. Allen, C.A.W., Watts, K.C., Ackman, R.G., Pegg, M.J., 1999. Predicting the viscosity of biodiesel fuels from their fatty acid ester composition. Fuel 78, 1319-1326.

6. Anonymous, 2015. European and international lubricant market, lpc.gr/en/themarket/european-and-international-lubricant-market/, accessed 12/2017.

7. Anonymous, 2016. Biolubricants Market Analysis By Raw Material (Vegetable \& Animal Oil), By Application (Automotive (Automotive Engine Oils, Gear Oils, Hydraulic Oils, Transmission Fluids, Greases, Chainsaw Oils), Industrial (Process Oils, Demolding Oils, Industrial Gear Oils, Industrial Greases, Metal Working Fluids)), By End-Use (Industrial, Commercial Transportation, Consumer Automotive) Segment Forecasts To 2024, www.grandviewresearch.com/industry-analysis/biolubricantsindustry, accessed 12/2017.

8. Asadauskas, S., Erhan, S.Z., 1999. Depression of pour points of vegetable oils by blending with diluents used for biodegradable lubricants. J. Am. Oil Chem. Soc. 76, 313316. 
9. Bandhu, S., Khot, M.B., Sharma, T., Sharma, O.P., Dasgupta, D., Mohapatra, S., Hazra, S., Khatri, O.P., Ghosh, D., 2018. Single Cell Oil from Oleaginous Yeast Grown on Sugarcane Bagasse- Derived Xylose: An Approach toward Novel Biolubricant for Low Friction and Wear. ACS Sustain. Chem. Eng. 6, 275-283.

10. Bock, W., 2007. Hydraulic Oils, in: Mang, T., Dresel, W. (Eds.), Lubricants and Lubrication. Wiley-VCH, Weinheim, pp. 274-337.

11. Cavalcanti, E.D.C., Aguieiras, É.C.G., Priscila, R., Duarte, J.G., Cipolatti, E.P., Fernandez-Lafuente, R., da Silva, J.A.C., Freire, D.M.G., 2018. Improved production of biolubricants from soybean oil and di ff erent polyols via esteri fi cation reaction catalyzed by immobilized lipase from Candida rugosa. Fuel 215, 705-713.

12. Chang, T.-S., Masood, H., Yubus, R., Rashid, U., Choong, T.S.Y., Biak, D.R.A., 2012. Activity of Calcium Methoxide Catalyst for Synthesis of High Oleic Palm Oil Based Trimethylolpropane Triesters as Lubricant Base Stock. Ind. Eng. Chem. Res. 51, 54385442.

13. da Silva, J.A.C., Soares, V.F., Fernadez-Lafuente, R., Habert, A.C., Freire, D.M.G., 2015. Enzymatic production and characterization of potential biolubricants from castor bean biodiesel. J. Mol. Catal. B. Enzym. 122, 323-329.

14. Fernandes, K.V., Papadaki, A., da Silva, J.A.C., Fernandez-Lafuente, R., Koutinas, A.A., Freire, D.M.G., 2018. Enzymatic esterification of palm fatty-acid distillate for the production of polyol esters with biolubricant properties. Ind. Crops Prod. 116, 90-96.

15. Ferreira-Leitão, V., Cammarota, M., Gonçalves Aguieiras, E., Vasconcelos de Sá, L., Fernandez-Lafuente, R., Freire, D., 2017. The Protagonism of Biocatalysis in Green Chemistry and Its Environmental Benefits. Catalysts 7, 1-34.

16. Fox, N.J., Stachowiak, G.W.Ã., 2007. Vegetable oil-based lubricants - A review of oxidation. Tribol. Int. 40, 1035-1046. 
17. Garcés, R., Martínez-Force, E., Salas, J.J., 2011. Vegetable oil basestocks for lubricants. Grasas Aceites, 62, 21-28.

18. Greco-Duarte, J., Cavalcanti-Oliveira, E.D., Da Silva, J.A.C., Fernandez-Lafuente, R., Freire, D.M.G., 2017. Two-step enzymatic production of environmentally friendly biolubricants using castor oil: Enzyme selection and product characterization. Fuel 202, 196-205.

19. Gutarra, M.L.E., Godoy, M.G., Maugeri, F., Rodrigues, M.I., Freire, D.M.G., Castilho, L.R., 2009. Production of an acidic and thermostable lipase of the mesophilic fungus Penicillium simplicissimum by solid-state fermentation. Bioresour. Technol. 100, 52495254.

20. Hwang, H., Erhan, S.Z., 2001. Modification of Epoxidized Soybean Oil for Lubricant Formulations with Improved Oxidative Stability and Low Pour Point. J. Am. Oil Chem. Soc. $78,1179-1184$.

21. Kachrimanidou, V., Kopsahelis, N., Chatzifragkou, A., Papanikolaou, S., Yanniotis, S., Kookos, I, Koutinas, A.A., 2013. Utilisation of By-Products from Sunflower-Based Biodiesel Production Processes for the Production of Fermentation Feedstock. Waste Biomass Valor. 4, 529-537.

22. Knothe, G., Dunn, R.O., 2009. A Comprehensive Evaluation of the Melting Points of Fatty Acids and Esters Determined by Differential Scanning Calorimetry. J. Am. Oil Chem. Soc. 86, 843-856.

23. Kopsahelis, N., Dimou, C., Papadaki, A., Xenopoulos, E., Kyraleou, M., Kallithraka, S., Kotseridis, Y., Papanikolaou, S., Koutinas, A.A., 2018. Refining of wine lees and cheese whey for the production of microbial oil, polyphenol-rich extracts and value-added coproducts. J. Chem. Techol. Biotechnol. 93, 257-268. 
24. Koutinas, A., Belafi-Bako, K., Babiri-Badr, A., Toth, A., Gubicza, L., Webb, C., 2001. Enzymatic hydrolysis of polysaccharides: Hydrolysis of starch by an enzyme complex from fermentation by Aspergillus awamori. Food Bioprod. Process. 79, 41-45.

25. Leiva-Candia, D.E., Tsakona, S., Kopsahelis, N., García, I.L., Papanikolaou, S., Dorado, M.P., Koutinas, A.A., 2015. Biorefining of by-product streams from sunflower-based biodiesel production plants for integrated synthesis of microbial oil and value-added coproducts. Bioresour. Technol. 190, 57-65.

26. Louhasakul, Y., Cheirsilp, B., Maneerat, S., Prasertsan, P. 2018. Direct transesterification of oleaginous yeast lipids into biodiesel: Development of vigorously stirred tank reactor and process optimization. Biochem. Eng. J. 137, 232-238.

27. Macpherson, I., 1997. Biodegradable pour point depressants for industrial fluids derived from biodegradable base oils. 5,658,864.

28. Ming, T.C., Ramli, N., Lye, O.T., Said, M., Kasim, Z., 2005. Strategies for decreasing the pour point and cloud point of palm oil products. Eur. J. Lipid Sci. Technol. 107, 505-512.

29. Mobarak, H.M., Mohamad, E.N., Masjuki, H.H., Kalam, M.A., Al Mahmud, K.A.H., Habibullah, M., Ashraful, A.M., 2014. The prospects of biolubricants as alternatives in automotive applications, Renew. Sust. Energ. Rev. 33, 34-43.

30. Papadaki, A., Mallouchos, A., Efthymiou, M.-N., Gardeli, C., Kopsahelis, N., Aguieiras, E.C.G., Freire, D.M.G., Papanikolaou, S., Koutinas, A.A., 2017. Production of wax esters via microbial oil synthesis from food industry waste and by-product streams. Bioresour. Technol. 245, Part A, 274-282.

31. Pryde, E.H., 1983. Utilization of commercial oilseed crops. Econ. Bot. 37, 459-477.

32. Quiao, S., Shi, Y., Wang, X., Lin, Z., Jiang, Y., 2017. Synthesis of Biolubricant Trimethylolpropane Trioleate and Its Lubricant Base Oil Properties. Energy Fuels, 31, 7185-7190. 
33. Rajewski, T.E., Fokens, J.S., Watson, M.C., 2000. The development and application of synthetic food grade lubricants. Ind. Lubr. Tribol. 52, 110-116.

34. Robles-Medina, A., González-Moreno, P.A., Esteban-Cerdán, L., Molina-Grima, E., 2009. Biocatalysis: Towards ever greener biodiesel production. Biotechnol. Adv. 27, 398-408.

35. Sarin, A., Arora, R., Singh, N.P., Sarin, R., Malhotra, R.K., Kundu, K., 2009. Effect of blends of Palm-Jatropha-Pongamia biodiesels on cloud point and pour point. Energy 34, 2016-2021.

36. Sharma, R.V., Somidi, A.K.R., Dalai, A.K., 2015. Preparation and Properties Evaluation of Biolubricants Derived from Canola Oil and Canola Biodiesel. J. Agric. Food Chem. $63,3235-3242$.

37. Singh, R.K., Kukrety, A., Singh, A.K., 2014. Study of novel ecofriendly multifunctional lube additives based on pentaerythritol phenolic ester. ACS Sustain. Chem. Eng. 2, 19591967.

38. Singh, Y., Garg, R., Kumar, S., 2015. Aspects of non-edible vegetable oil-based biolubricants in the automotive sector. Green 5, 59-72.

39. Sripada, P.K., Sharma, R. V., Dalai, A.K., 2013. Comparative study of tribological properties of trimethylolpropane-based biolubricants derived from methyl oleate and canola biodiesel. Ind. Crops Prod. 50, 95-103.

40. Ting, C., Chen, C., 2011. Viscosity and working efficiency analysis of soybean oil based. Measurement 44, 1337-1341.

41. Tsakona, S., Kopsahelis, N., Chatzifragkou, A., Papanikolaou, S., Kookos, I.K., Koutinas, A.A., 2014. Formulation of fermentation media from flour-rich waste streams for microbial lipid production by Lipomyces starkeyi. J. Biotech. 189, 36-45. 
42. Tsakona, S., Skiadaresis, A.G., Kopsahelis, N., Chatzifragkou, A., Papanikolaou, S., Kookos, I.K., Koutinas, A.A., 2016. Valorisation of side streams from wheat milling and confectionery industries for consolidated production and extraction of microbial lipids. Food Chem. 198, 85-92.

43. Uosukainen, E., Linko, YY., Lämsä, M., Tervakangas, T., Linko, P., 1998. Transesterification of trimethylolpropane and rapeseed oil methyl ester to environmentally acceptable lubricants. J. Amer. Oil Chem. Soc. 75, 1557-1563.

44. VanVoorst, R., Alam, F., 2000. Polyglycols as base fluids for environmentally-friendly lubricants. Lubr. Sci. 16, 313-322.

45. Wang, E., Ma, X., Tang, S., Yan, R., Wang, Y., Riley, W.W., Reaney, M.J.T., 2014. Synthesis and oxidative stability of trimethylolpropane fatty acid triester as a biolubricant base oil from waste cooking oil. Biomass Bioenergy 66, 4-11.

46. Zheng, H., Zhang, R., Zhang, H., Feng, Y., Li, K., Zhang, W., 2011. Thermal analysis of four insect waxes based on differential scanning calorimetry (DSC). Procedia Eng. 18, 101-106. 


\section{Figure captions}

Figure 1. Time course of biolubricant production by enzymatic esterification using the hydrolysed microbial oil of $C$. curvatus with NPG (घ) and TMP (•).

Figure 2. Time course of biolubricant production by enzymaic esterification using the hydrolysed microbial oil of $R$. toruloides with NPG (घ) and TMP (•).

Figure 3. Differential scanning calorimetry analysis for NPG esters produced from the hydrolysed microbial oil of (a) R. toruloides and (b) C. curvatus. 
Table 1. Batch fermentations of oleaginous yeast and fungal strains using flour-rich waste derived hydrolysate as substrate

\begin{tabular}{|c|c|c|c|c|c|}
\hline $\begin{array}{c}\text { Oleaginous } \\
\text { microorganisms }\end{array}$ & $\begin{array}{l}\text { Fermentation } \\
\text { time (h) }\end{array}$ & $\begin{array}{c}\text { Sugars } \\
\text { consumed } \\
(\mathrm{g} / \mathrm{L})\end{array}$ & $\begin{array}{l}\text { TDW } \\
(\mathrm{g} / \mathrm{L})\end{array}$ & $\begin{array}{c}\text { Lipids } \\
\text { (g/L) }\end{array}$ & $\begin{array}{c}\text { Lipid } \\
\text { content } \\
(\%, w / w)\end{array}$ \\
\hline $\begin{array}{l}\text { C. curvatus } \\
\text { NRRL Y-1511 }\end{array}$ & 216 & 89.9 & 29.6 & 1.6 & 5.4 \\
\hline $\begin{array}{l}\text { C. curvatus } \\
\text { ATCC } 20509\end{array}$ & 154 & 90.0 & 35.2 & 58 & 16.5 \\
\hline $\begin{array}{l}\text { R. toruloides } \\
\text { DSM } 4444\end{array}$ & 168 & 86.3 & & 9.5 & 41.1 \\
\hline $\begin{array}{l}\text { R. toruloides } \\
\text { NRRL Y-27012 }\end{array}$ & 196 & 81.9 & & 5.4 & 30.2 \\
\hline $\begin{array}{l}R . \text { glutinis } \\
\text { NRRL YB-252 }\end{array}$ & 333 & & 19.9 & 3.2 & 16.1 \\
\hline C. echinulata & 330 & & 26.1 & 9.2 & 35.3 \\
\hline $\begin{array}{l}\text { M. ramanniana } \\
\text { MUCL } 9235\end{array}$ & 300 & 89.7 & 29.4 & 11.7 & 39.8 \\
\hline
\end{tabular}


Table 2. Fatty acid composition of microbial oils derived from yeast and fungal strains in batch fermentations using flour-rich waste derived hydrolysate

\begin{tabular}{|c|c|c|c|c|c|c|c|c|}
\hline \multirow{2}{*}{$\begin{array}{l}\text { Microbial } \\
\text { Strains }\end{array}$} & \multicolumn{7}{|c|}{ Fatty acid composition (\%) } & \multirow{2}{*}{$\begin{array}{c}\text { Content of } \\
\text { saturated fatty } \\
\text { acids }(\%)\end{array}$} \\
\hline & C14:0 & C16:0 & C16:1 & C18:0 & C18:1 & C18:2 & ${ }^{{ }^{9,12,15}} \mathrm{C} 18: 3^{{ }^{46,9,12}} \mathrm{C} 18: 3^{\mathrm{a}}$ & \\
\hline $\begin{array}{l}R . \text { toruloides } \\
\text { DSM } 4444\end{array}$ & 1.5 & 28.2 & 0.5 & 6.5 & 53.2 & 8.8 & 1.1 & 36.2 \\
\hline $\begin{array}{l}\text { R. toruloides } \\
\text { NRRL Y-27012 }\end{array}$ & 1.4 & 24.2 & 0.7 & 6.7 & 55.3 & 9.5 & 2.1 & 32.3 \\
\hline $\begin{array}{l}\text { C. curvatus } \\
\text { ATCC } 20509\end{array}$ & 0.5 & 26.3 & 0.9 & 10.8 & 52.7 & 7.4 & - & 37.6 \\
\hline $\begin{array}{l}\text { M. ramanniana } \\
\text { MUCL } 9235\end{array}$ & 1.0 & 20.8 & 0.7 & 3.7 & 49.0 & & 7.1 & 25.5 \\
\hline C. echinulata & 0.4 & 15.1 & 1.2 & 2.9 & 49.3 & 17.5 & 11.8 & 18.4 \\
\hline
\end{tabular}

${ }^{\mathrm{a}} \gamma$-linolenic acid (GLA) 
Table 3. NMR analysis of biolubricants produced at $24 \mathrm{~h}$ via esterification of TMP and hydrolysed microbial oils of $R$. toruloides and C. curvatus

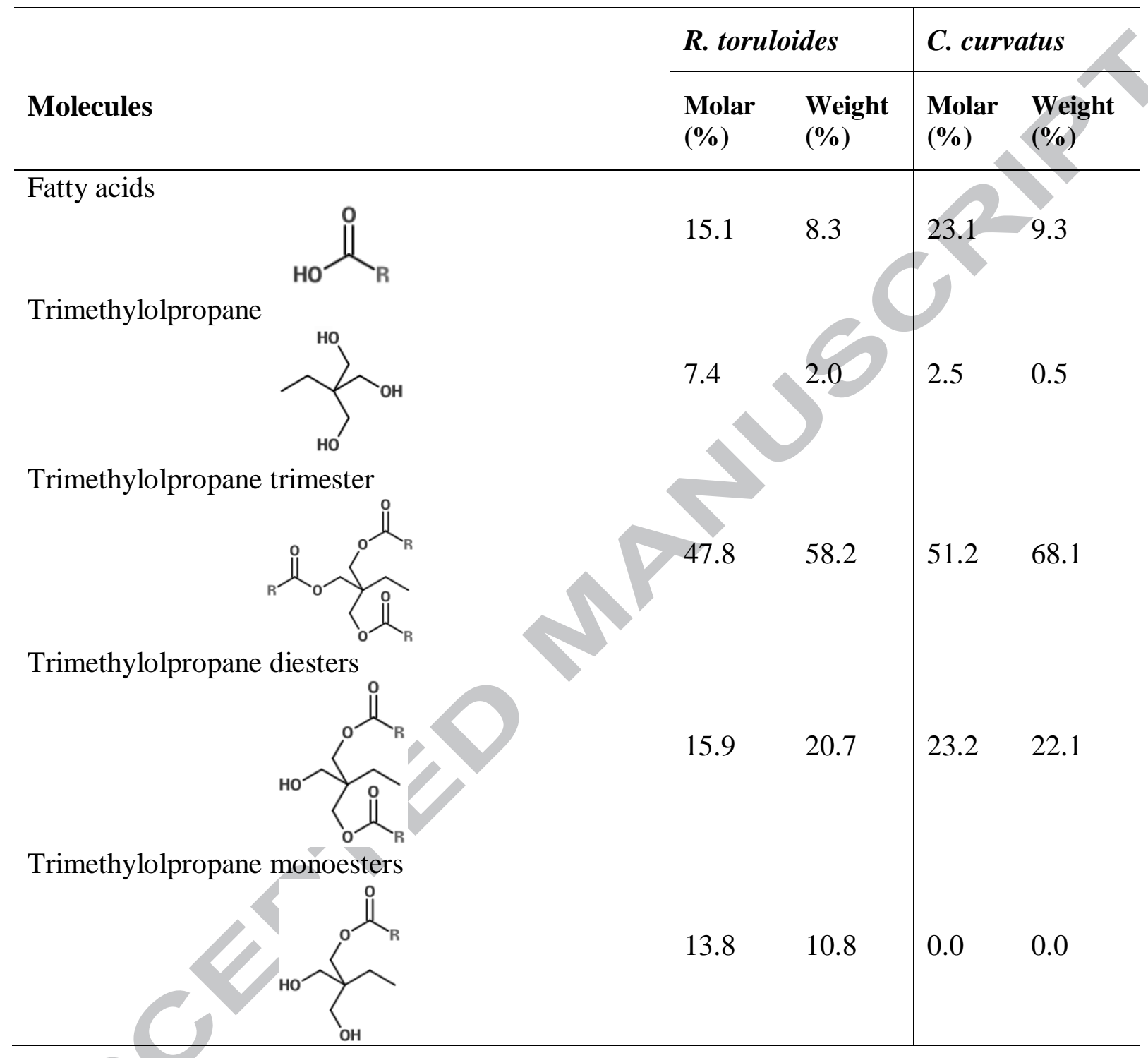


Table 4. NMR analysis of biolubricants produced at $24 \mathrm{~h}$ via esterification of NPG and hydrolysed microbial oils of $R$. toruloides and C. curvatus

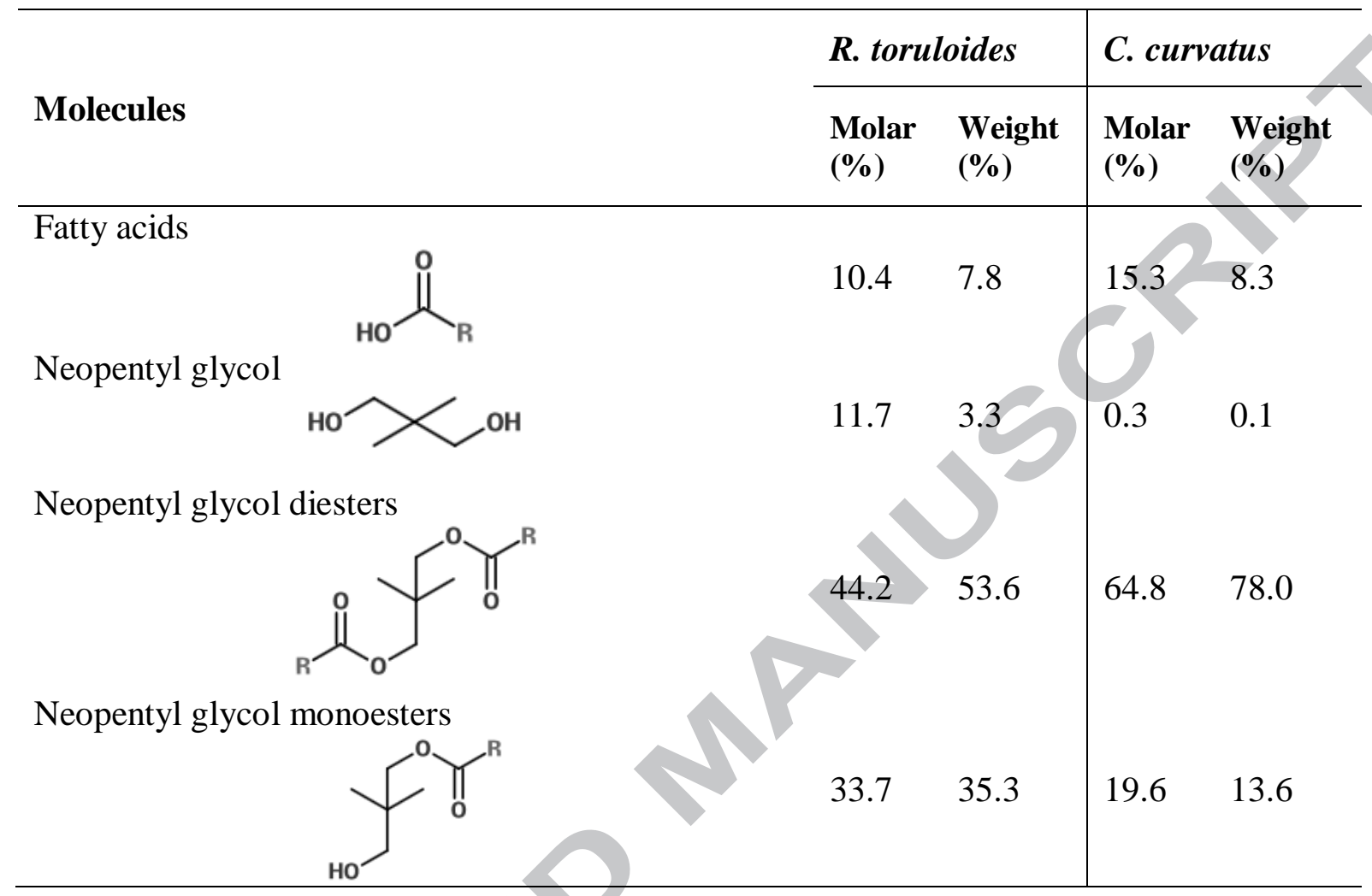


Table 5. Physical and chemical characterization of NPG esters produced using the hydrolyzed microbial oils of $R$. toruloides and C. curvatus

\begin{tabular}{lll}
\hline \multicolumn{1}{c}{ Properties } & R. toruloides esters & C. curvatus esters \\
\hline Viscosity $40{ }^{\circ} \mathrm{C}\left(\mathrm{mm}^{2} / \mathrm{s}\right)$ & 22.33 & 23.84 \\
Viscosity $100{ }^{\circ} \mathrm{C}\left(\mathrm{mm}^{2} / \mathrm{s}\right)$ & 5.26 & 5.54 \\
Viscosity index & 181.0 & 183 \\
Acidity index $(\mathrm{mg} \mathrm{KOH} / \mathrm{g})$ & 10.36 & 12.13 \\
Pour Point $\left({ }^{\circ} \mathrm{C}\right)$ & 3.0 & 2 \\
Cloud Point $\left({ }^{\circ} \mathrm{C}\right)$ & 4.0 & 6 \\
Oxidative stability $(\mathrm{h})$ & 3.29 & 4.18 \\
\hline
\end{tabular}


Figure 1

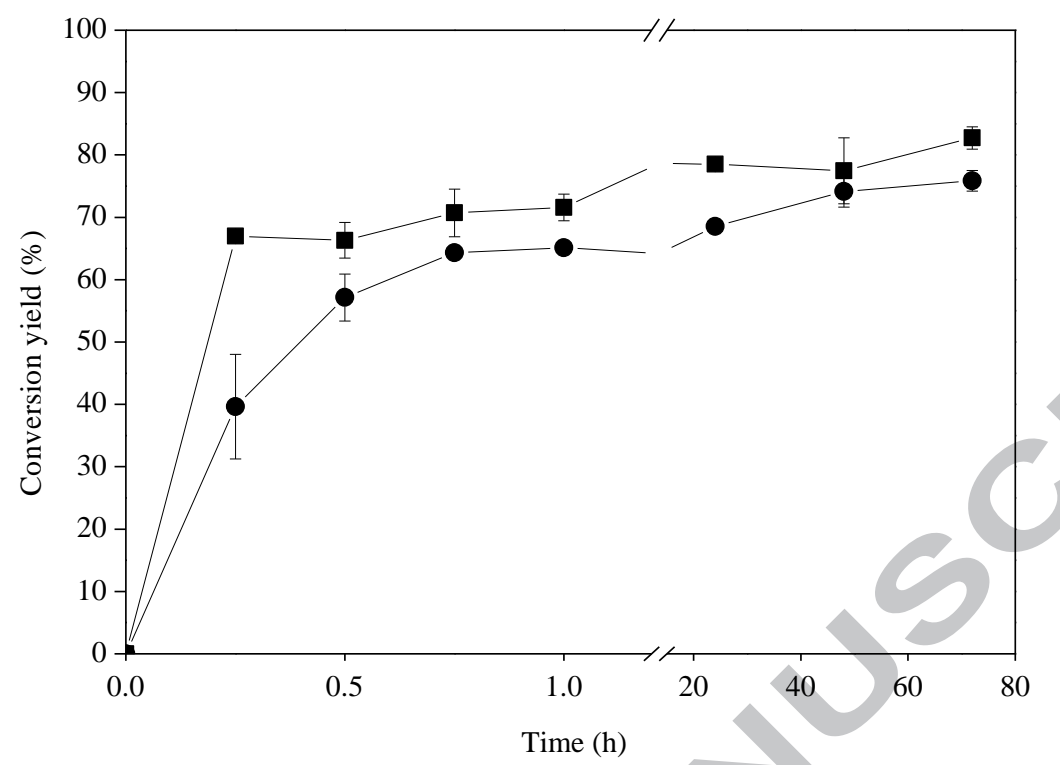


Figure 2

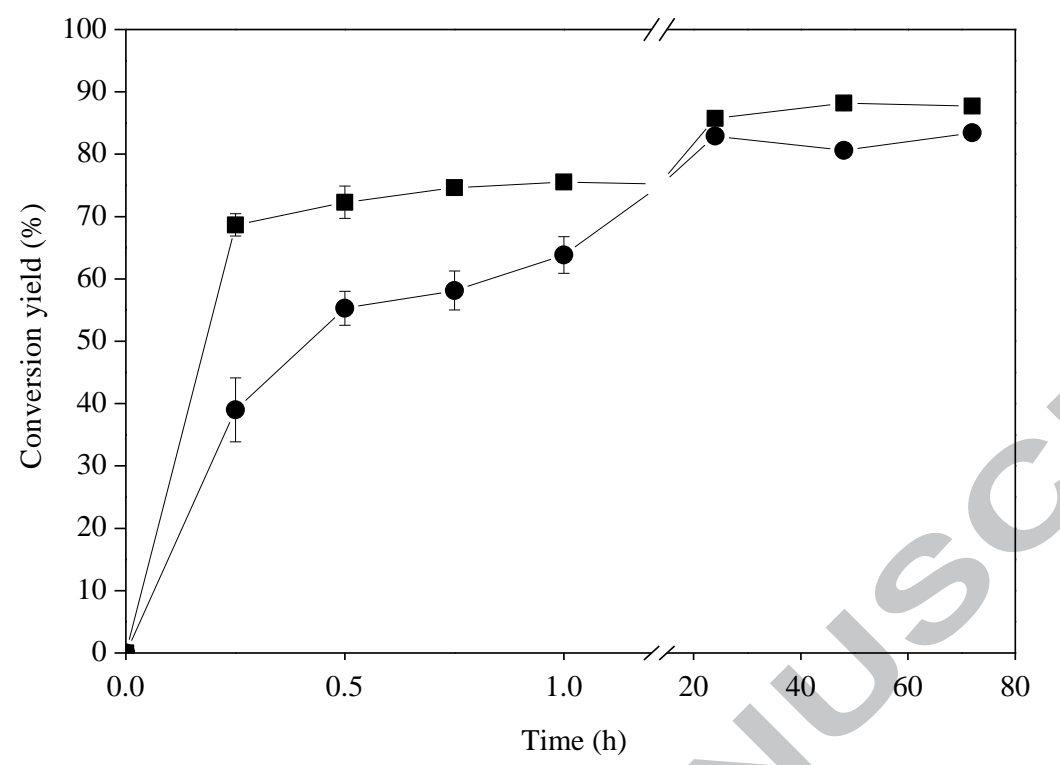


Figure 3
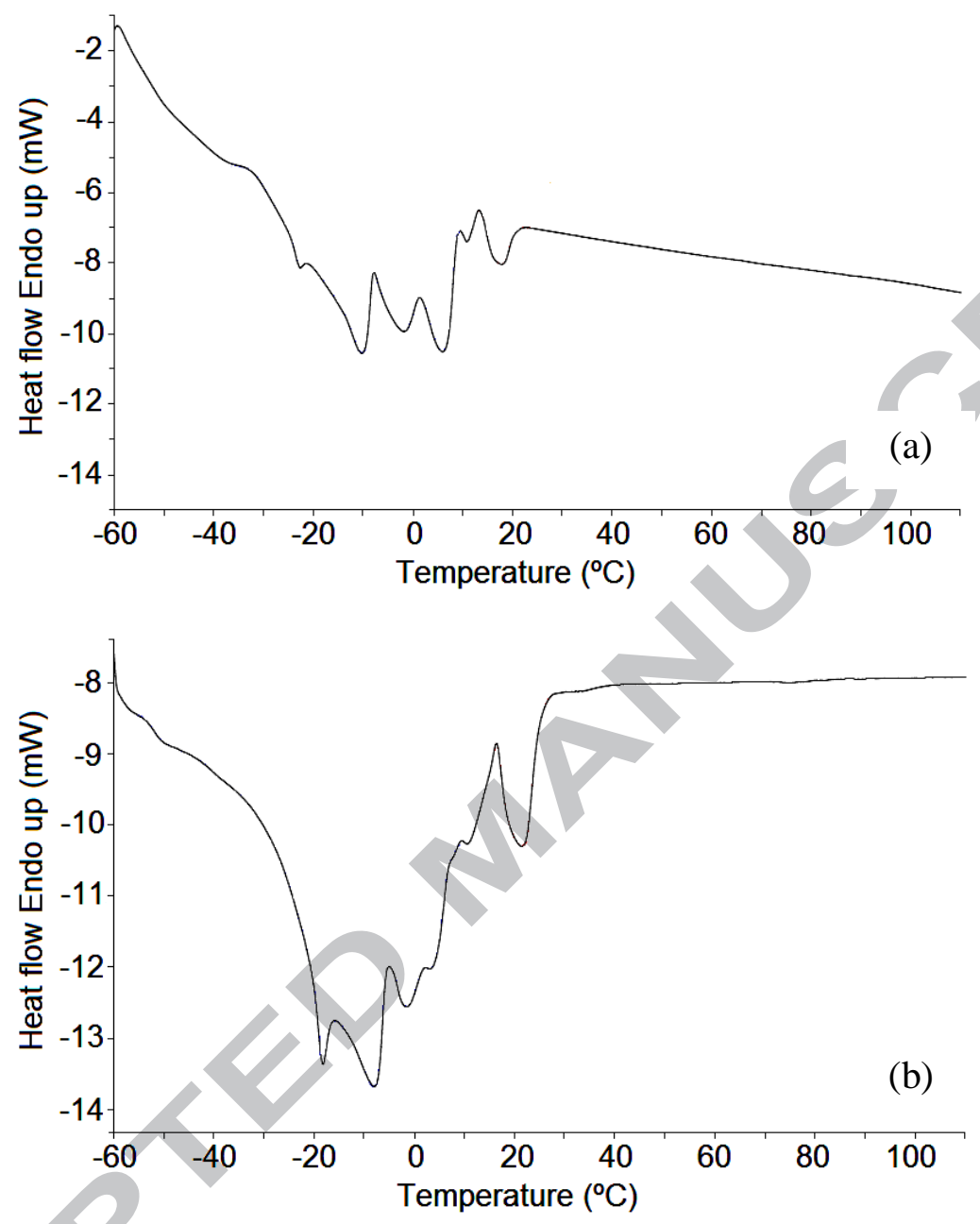
A. Pandey,

Editor-in-Chief of Bioresource Technology

Biotechnology Division, National Inst. for Interdisciplinary Science \& Technology,

CSIR, Trivandrum 695 019, India,

Fax: +914712491712,

Phone: +914712515279

Dear Editor,

Kindly find below the "Highlights" of the manuscript entitled "Bioprocess development for biolubricant production using microbial oil derived via fermentation from confectionery industry waste" which is submitted for consideration for publication in Bioresource Technology.

Highlights of the manuscript:

- Biolubricant production from microbial oil derived from food industry waste

- Solvent-free enzymatic catalysis was employed for biolubricant production

- The highest conversion yield of neopentyl glycol esters was $88 \%$

- The highest conversion yield of trimethylolpropane esters was $83 \%$

- Esters from microbial oil showed promising lubricant properties

Yours sincerely,

Dr. A. Koutinas

Corresponding author 